\title{
BIOGEOGRAPHY, INVENTORY AND NEW DATA ON REPTILES OF M'SILA REGION, ALGERIA
}

\author{
Hadj Aissa Benelkadi ${ }^{\mathrm{a}}$, Adel Mammeri $^{\mathrm{b} *}$ and Mansour Amroun ${ }^{\mathrm{a}}$
}

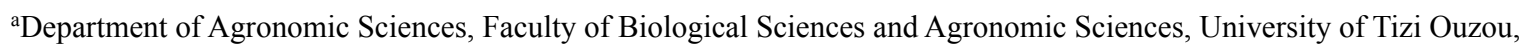 \\ PB 15017, Tizi Ouzou 015000, Algeria

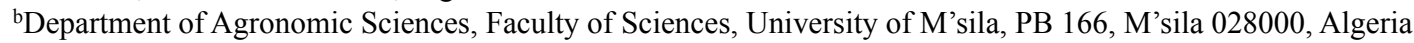 \\ *Corresponding author. Email: adel.mammeri@univ-msila.dz
}

\begin{abstract}
Article history
Received: 2 August 2021;

accepted: 17 September 2021
\end{abstract}

\section{Keywords:}

Reptile inventory; M'sila; habitat loss; threatened species

\begin{abstract}
This study is the first contribution to the evaluation of reptile diversity in different habitats of M'sila region, Algeria. We carried out 94 trips between 2016 and 2018 across three sites: Mergueb (six stations), L'mhazem (three stations) and Kaf Afoul (two stations), on average, accompanied by prospectors. Our aims were to make an inventory of reptilian species in this region, as well as to study their diversity, distribution, ecology and abundance. Altogether, we recorded 193 specimens belonging to 22 species: two turtles, one amphisbaenian, twelve lizards and seven snakes. Two species classified as Near Threatened by the IUCN were recorded: Uromastyx acanthinurus (Bell, 1825 ) and Daboia mauritanica (Duméril \& Bibron, 1848). Statistical analysis revealed that the type of habitat directly influences the distribution of reptiles in the study area. Although this small area is rich in reptilian species, their abundance remains low and worrying.
\end{abstract}

\section{INTRODUCTION}

Herpetofaunal species are among the most threatened vertebrates in the world (Stuart et al. 2004) suffering massive declines due to habitat loss and degradation, pollution and climate change (Musah et al. 2019). In 2017, there were 10,450 recorded reptile species (Uetz et al. 2017), of which 398 are distributed throughout the Mediterranean basin, most of which are endemic (Çiçek and Cumhuriyet 2017).

According to a study by Bush et al. (2014), international trade in exotic animals is a significant and growing factor in biodiversity loss, and often undermines the required standards of animal welfare and level of threat and legal protection of traded species. Furthermore, Foufopoulos et al. (2011) suggest that recent climate change has resulted in a poleward shift in the distribution of many reptile species. More recently, in the same context, Carter et al. (2021) report that reptiles, whose sex determination is temperaturedependent, are particularly vulnerable to even small-scale variation in incubation conditions and are a model system for studying the impacts of temperature changes on physiological traits. In a large-scale survey, Böhm et al. (2016) found that $80.5 \%$ of reptile species were highly sensitive to climate change, mainly due to habitat specialisation, while $48 \%$ had low adaptive capacity, and $58 \%$ high exposure. According to the same authors, $22 \%$ of the species assessed were highly vulnerable to climate change. Nevertheless, some recent studies report that $70 \%$ of all tortoise species are on the verge of extinction due to human influence (Stanford et al. 2020; Graciá et al. 2020).
Reptiles are the only group without a complete analysis of biogeography in The Afro-Arabian region, and the Maghreb region comprises one of the most important biogeographic zones linking the continents (Soultan et al. 2020). Despite this, few studies have focused on understanding its endemic fauna (Soultan et al. 2020).

Algeria's particular geographical position at the biogeographical crossroads between the Mediterranean, SaharanSindian and Ethiopian regions, its large surface area of $2,381,741 \mathrm{~km}^{2}$, the ambitions of this country to protect its natural heritage, the various biodiversity hotspots that this country contains and all the gaps in knowledge of biodiversity make this country a very interesting case study for the herpetofauna. Especially that it is one of the least studied Maghreb countries in terms of reptile ecology (Bons and Geniez 1996; Schleich et al. 1996; Beddek 2017). According to Cox et al. (2006) and Bouazza et al. (2021), Algeria, Egypt and Morocco contain the highest herpetological diversity in the Mediterranean basin.

The first elements concerning knowledge of the herpetological fauna of Algeria appeared during the late $18^{\text {th }}$ century, with the first notes by Shaw (1738), Poiret (1789), Rozet (1833), Gervais (1835, 1836, 1844), Guichenot (1850), Tristram (1859), Strauch (1862) and Boulenger (1891). At the beginning of the $20^{\text {th }}$ century, Doumergue (1901) published a very important work entitled "Essay on the herpetological fauna of Orania", which remains a reference on the subject for many species, and in which several notes overall of Algeria are included.

At the end of the $20^{\text {th }}$ century, Le Berre (1989) dedicated a section to the herpetofauna of Algeria, followed by 
an important book on the herpetofauna of North Africa entitled "Amphibians and Reptiles of North Africa" (Schleich et al. 1996). Nevertheless, this remains insufficient compared to the large area of the country, as well as to the richness and diversity of ecosystems in Algeria. To this day, few studies are published in this context: Rouag and Benyakoub 2006; Mamou 2011; Rouag 2012; Mamou et al. 2014; Dellaoui et al. 2015; Mamou and Marniche 2016; and Ferrer et al. 2016. However, when mapping the distribution of the sampling effort in Algeria, it turned out that most of the herpetofauna in the country is not at all or very little explored (Beddek 2017).

Apart from the still widespread practice of killing anything remotely resembling a snake, the factors contributing to the depletion of Algeria's herpetofauna are far more serious and numerous (Rouag 2012). The lack of information about these threats, coupled with the predicted rising of human population density in Africa, would increase the risk of extinction of African reptile species (Jordaan 2019). According to Soultan et al. (2020) many previous works (Rodrigues et al. 2015; Brito et al. 2016) confirm that analyses at smaller spatial scales allow a better identification of important conservation areas that might not be identified at large scales. Therefore, the main objective of this study is to know the biogeographical diversity of reptiles in the Mergueb nature reserve and its surroundings located in the territory of the M'sila region, which is almost totally unknown.

\section{MATERIALS AND METHODS}

\section{Study area}

The region of M'sila is located in the northeast of Algeria (Figure 1), in the middle arid bioclimatic zone with a cold winter according to Emberger's rainfall quotient $(\mathrm{Q} 2=$ 15.62). Its wettest month is September with an average rainfall of $25.6 \mathrm{~mm}$, while July is the least rainy month with an average rainfall of $3.75 \mathrm{~mm}$. January is the coldest month, with an average minimum temperature of $8.41^{\circ} \mathrm{C}$; however, July is the hottest month, with an average maximum temperature of $31.11^{\circ} \mathrm{C}$ (Adjabi et al. 2019).

\section{Sampling sites}

Three study sites were chosen, located $150 \mathrm{~km}$ south of Algiers on National Road $\mathrm{N}^{\circ} 8$, in the northern limit of the wilaya of M'sila and at the limits of the wilayas of Médéa and Bouira (Figure 1).

From these 3 sites, 11 stations were selected, based on differences in exposure, altitude, soil type and vegetation. The 3 sites show the following characteristics (Figure 2):

Mergueb (6 stations): it is a nature reserve located in the high steppe plains region, with a northern latitude of $35^{\circ} 36^{\prime}$ and an eastern longitude of $03^{\circ} 56^{\prime}$, in the west of the wilaya of M'sila, at an average altitude of $620 \mathrm{~m}$, and with a surface area of 16481 ha.

L'mhazem (3 stations): it represents a mountain which owes its name to its top which resembles a belt, located in the west of the wilaya of M'sila, in the southern administrative limit of the wilaya of Bouira, at an average altitude of $941.5 \mathrm{~m}$, with a northern latitude of $35^{\circ} 54^{\prime}$ and an eastern longitude of $04^{\circ} 00^{\prime}$. This Mountain constitutes the northern limits of the steppe rangelands, beyond which begins the Atlas Tellien massif.

Kaf Afoul (2 stations): it is another mountain located in the limit of the wilaya of Médéa at $120 \mathrm{~km}$ west of the wilaya of M'sila, it has an average altitude of $769.2 \mathrm{~m}$,

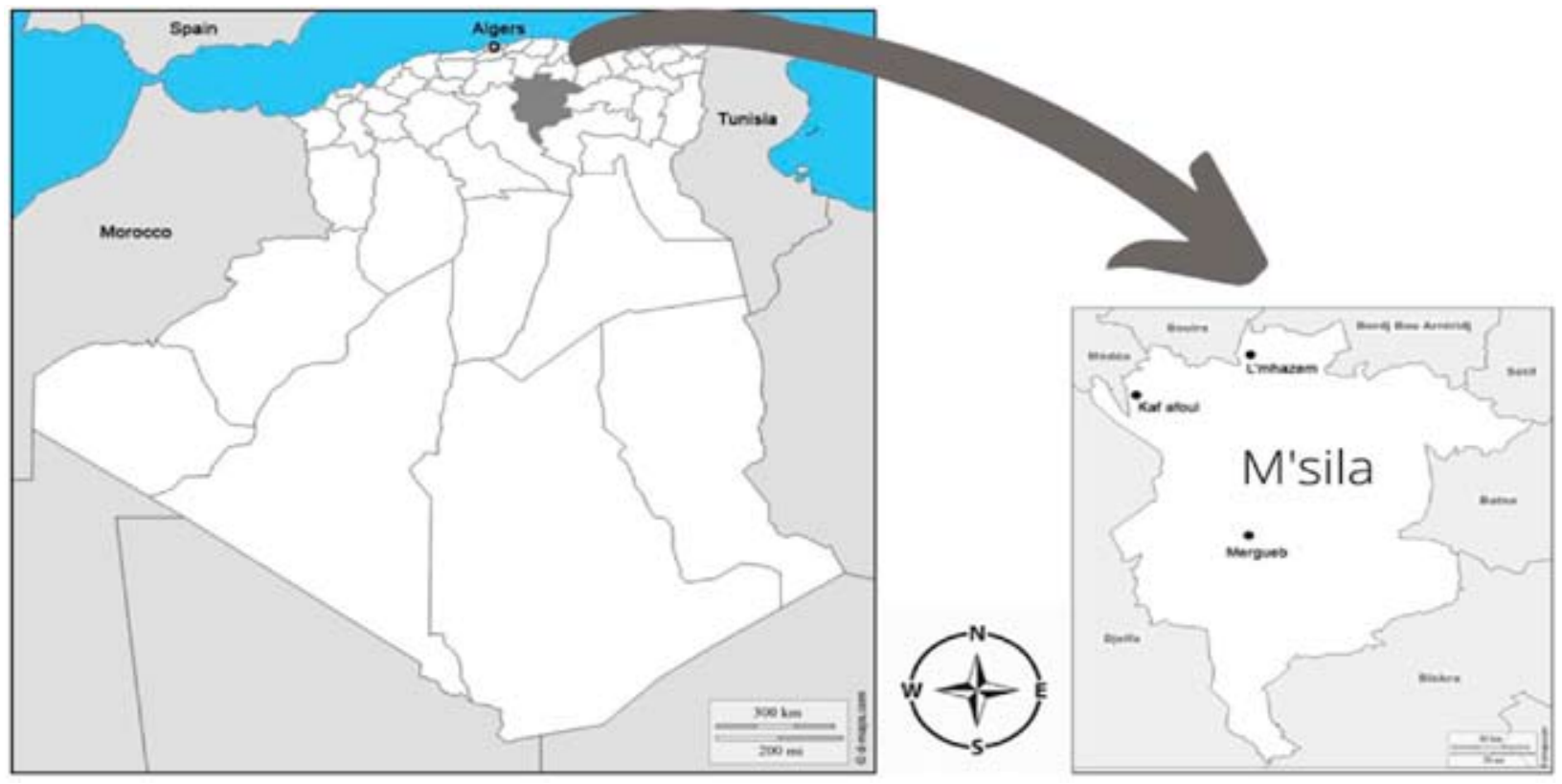

Figure 1. Geographical location of the wilaya of M'sila and distribution of study sites. 


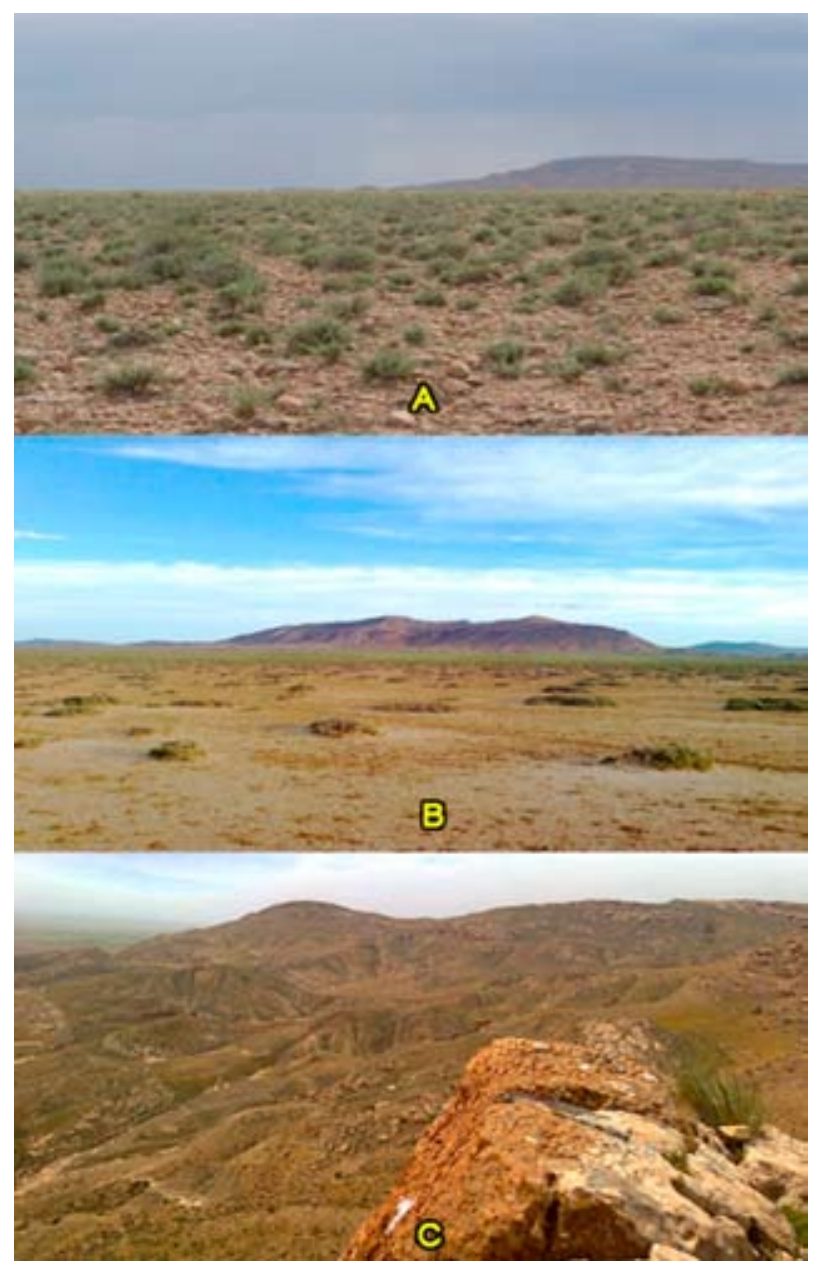

Figure 2. Study sites: Mergueb (A), L'mhazem (B), and Kaf Afoul (C).

a northern latitude of $35^{\circ} 54^{\prime}$ and an eastern longitude of $03^{\circ} 34^{\prime}$. This mountain also constitutes the northern limits of the steppe areas, beyond which the massif of the Atlas Tellien begins.

It was found that the selected sites consisted mainly of 5 different habitats that could be suitable shelters for reptile life. Thus, the dominant plant species were recorded and their coverage was visually assessed as a percentage of the ground surface (Incorvaia 2005):

Mountain ridge (MR): more or less flat and fragmented rocky slabs, with vegetation cover reaching up to $40 \%$ and composed mainly of clumps of Pituranthos scoparius, Alyssum montanum, Sedum caeruleum and Astragalus armatus.

Mountain bottom (MB): less covered than the MR, the soil is very uneven and rocky; the different species of the genus Stipa are found here.

Hamada (HM): this term refers to a horizontal rocky plateau surrounded by well-marked cliffs, which give them the appearance of gigantic tables. The HMs are characterised by an abundance of bare, wind-worn and polished rock, with very sparse vegetation cover.
Daya (DY): DYs are closed basins of limited extent found in flat land. They are visible to any observer because they form patches of vegetation on the bare surface of the HMs. They vary greatly in diameter; from a few metres to exceptionally a few kilometres. The bottom of the DYs is clogged with clay, silt and gravel, and the pools that form after rainfall are quite long-lasting. Water infiltrates slowly, so the soil remains wet for a long time. This environment is often used for cereal cultivation and grazing, and the average vegetation cover is sometimes as high as $50 \%$. The DY is mainly made up of xerophytic and halophytic plants, especially: Artemisia herba-alba, Salsola vermiculata, Zizyphus lotus, Anabasis articulata, Atriplex halimus and Stipa tenacissima.

Wadi bed (WB): this term refers to a watercourse with intermittent flow. It is a humid environment and well covered by plants, notably Zizyphus lotus, Anabasis articulata and Atriplex halimus.

\section{Survey methods}

Sampling reptiles does not require a lot of equipment, as subtlety, speed, attention and courage are more effective. So for our study, perhaps the simplest AR (Rapid assessments of reptile diversity) technique for reptiles is the 'visual survey by encounter' (VES), (Crump and Scott 1994; Guyer and Donnelly 2012; see Das 2016). However, most of the time we only used our hands, with the exception of a few sticks or a small shovel to dig a burrow. This technique is therefore preliminary and does not make it possible to claim an exhaustive investigation (Delzons et al. 2015).

We carried out the study during two years, between March 2016 and February 2018. On average, 2 trips were made per month, always accompanied by 2 to 3 prospectors. Thus, a total number of 94 outings were made, with a duration ranging from 2 to $4 \mathrm{~h}$ per trip: 18 outings for the MR, 16 for the MB, 30 for the DY, 9 for the WB, and 21 for the HM.

The best time for the different trips was in the morning. An identification document was filled in after capture or observation of each specimen, whether dead or alive or skin remains. Specimens were identified using determination keys of Schleich et al. (1996), Venchi and Sindaco (2006), Trape et al. (2012) and Geniez (2012).

\section{Exploitation indices of the collected data}

The results were analysed using the following indices:

\section{Ecological indices of structure}

Abundance frequency $($ FrqAb): $\mathrm{FrqAb}=(\mathrm{ni} / \mathrm{N}) \times$ 100 
- ni: number of individuals of a given species in each habitat.

$-\mathrm{N}$ : number of individuals of all species in each habitat.

Occurrence frequency (FrqOcc): $\mathrm{FrqOcc}=(\mathrm{pi} / \mathrm{P}) \times 100$

- pi: number of outings including a given species in each habitat.

$-\mathrm{P}$ : total number of outings in each habitat.

\section{Ecological indices of population diversity}

Total specific richness $(\boldsymbol{S})$ : defined as the total number of species recorded during all outings $(\mathrm{P})$ for each habitat.

Mean specific richness (Sm): this is the ratio of (S) to all outings $(\mathrm{P})$ towards each habitat: $\mathrm{Sm}=\mathrm{S} / \mathrm{P}$.

Shannon diversity index $\left(H^{\prime}\right)$ : best expresses the diversity of a population. It coordinates both abundance and species richness (Gray and Kennedy 1994): H' $=-\Sigma$ $(\mathrm{ni} / \mathrm{N}) \log _{2}(\mathrm{ni} / \mathrm{N})$.

Equitability index (E): obtained by relating the observed diversity to the maximum theoretical diversity $\left(\mathrm{H}^{\prime}{ }_{\max }=\right.$ $\left.\log _{2} \mathrm{~S}\right): \mathrm{E}=\mathrm{H}^{\prime} / \mathrm{H}^{\prime}{ }_{\text {max }}$.

Sorensen's Index (SI): in order to be able to state the similarity that exists in the composition of reptile populations in space: $\mathrm{SI}=\mathrm{C} /(\mathrm{S} 1+\mathrm{S} 2)$;

S1: number of species found in habitat 1 ;

S2: number of species found in habitat 2;

$\mathrm{C}$ : number of species found simultaneously in both habitats (1 and 2).
Statistical analysis: In order to know if the type of habitat influences the distribution of reptilian species in the study region, we used the Factorial Correspondence Analysis (FCA) method. The objective of using FCA is to analyze the link existing between the types of habitat with the reptilian species in our study. This method was applied using SPSS version 20 software.

\section{RESULTS}

Out of a total of 193 specimens, we were able to identify 22 species of reptiles divided into two orders (Chelonii and Squamata), 4 suborders (Chelonia, Amphisbaenia, Sauria and Ophidia), 13 families and 21 different genera, distributed on an approximate area of 70,000 ha.

Twenty of the identified species $(90.48 \%)$ belong to the order Squamata. These are divided into 11 families (Trogonophiidae, Chamaeleonidae, Scincidae, Lacertidae, Gekkonidae, Agamidae, Varanidae, Lamprophiidae, Colubridae, Viperidae and Boidae). The order Chelonii was poorly represented with only two species $(9.09 \%)$ in two families (Testudinidae and Geoemydidae) (Table 1).

Biogeographical status, protection and trophic categories

The biogeographical and trophic status of the species recorded is defined according to Schleich et al. (1996) (Table 2).

Table 1. Taxonomic classification of inventoried reptile species in the study area.

\begin{tabular}{|c|c|c|c|c|}
\hline Class & Order & Sub-order & Family & Species \\
\hline \multirow{13}{*}{ Reptilia } & \multirow{2}{*}{ Chelonii } & \multirow{2}{*}{ Chelonia } & Testudinidae & Testudo graeca \\
\hline & & & Geoemydidae & Mauremys leprosa \\
\hline & \multirow{11}{*}{ Squamata } & Amphisbaenia & Trogonophiidae & Trogonophis wiegmanni \\
\hline & & \multirow{6}{*}{ Sauria } & Chamaeleonidae & Chamaeleo chamaeleon \\
\hline & & & Scincidae & $\begin{array}{l}\text { Chalcides mertensi } \\
\text { Chalcides ocellatus }\end{array}$ \\
\hline & & & Lacertidae & $\begin{array}{l}\text { Mesalina olivieri } \\
\text { Acanthodactylus erythrurus } \\
\text { Psammodromus algirus }\end{array}$ \\
\hline & & & Gekkonidae & $\begin{array}{l}\text { Tarentola mauritanica } \\
\text { Stenodactylus sthenodactylus }\end{array}$ \\
\hline & & & Agamidae & $\begin{array}{l}\text { Agama impalearis } \\
\text { Uromastyx acanthinurus } \\
\text { Trapelus mutabilis }\end{array}$ \\
\hline & & & Varanidae & Varanus griseus \\
\hline & & \multirow{4}{*}{ Ophidia } & Lamprophiidae & $\begin{array}{l}\text { Malpolonmon spessulanus } \\
\text { Psammophis schokari }\end{array}$ \\
\hline & & & Colubridae & $\begin{array}{l}\text { Hemmorhois hippocrepis } \\
\text { Spalerosophis dolichospilus }\end{array}$ \\
\hline & & & Viperidae & $\begin{array}{l}\text { Daboia mauritanica } \\
\text { Cerastes cerastes }\end{array}$ \\
\hline & & & Boidae & Eryx jaculus \\
\hline
\end{tabular}


Table 2. Biogeographical, protection status and trophic categories of reptile species recorded in the study area.

\begin{tabular}{|c|c|c|c|}
\hline Species & $\begin{array}{l}\text { Biogeographi- } \\
\text { cal status }\end{array}$ & $\begin{array}{l}\text { Trophic } \\
\text { category }\end{array}$ & $\begin{array}{l}\text { IUCN } \\
\text { Red List } \\
\text { classifica- } \\
\text { tion }\end{array}$ \\
\hline Testudo graeca* & Maghrebin & $\mathrm{H}$ & LC \\
\hline Mauremys leprosa* & $\begin{array}{l}\text { Ibero- } \\
\text { Maghrebin }\end{array}$ & $\mathrm{C}$ & $\mathrm{LC}$ \\
\hline Trogonophis wiegmanni & Maghrebin & I & LC \\
\hline $\begin{array}{l}\text { Chamaeleo } \\
\text { chamaeleon* }\end{array}$ & Mediterranean & I & $\mathrm{LC}$ \\
\hline Chalcides mertensi & North-African & I & $\mathrm{LC}$ \\
\hline Chalcides ocellatus & Saharo-Sindian & I & $\mathrm{LC}$ \\
\hline Mesalina olivieri & Saharan & I & $\mathrm{LC}$ \\
\hline $\begin{array}{l}\text { Acanthodactylus } \\
\text { erythrurus }\end{array}$ & $\begin{array}{l}\text { Ibero- } \\
\text { Maghrebin }\end{array}$ & I & $\mathrm{LC}$ \\
\hline Psammodromus algirus & $\begin{array}{l}\text { Ibero- } \\
\text { Maghrebin }\end{array}$ & I & $\mathrm{LC}$ \\
\hline Tarentola mauritanica & Mediterranean & I & $\mathrm{LC}$ \\
\hline \begin{tabular}{|l} 
Stenodactylus \\
sthenodactylus
\end{tabular} & Saharan & I & $\mathrm{LC}$ \\
\hline $\begin{array}{l}\text { Uromastyx } \\
\text { acanthinurus* }\end{array}$ & Saharan & $\mathrm{H}$ & NT \\
\hline Trapelus mutabilis* & Saharan & I & $\mathrm{LC}$ \\
\hline Agama impalearis* & Maghrebin & I & $\mathrm{LC}$ \\
\hline Varanus griseus* & Saharo-Sindian & $\mathrm{C}$ & $\mathrm{LC}$ \\
\hline $\begin{array}{l}\text { Malpolonmon } \\
\text { spessulanus }\end{array}$ & Mediterranean & $\mathrm{C}$ & $\mathrm{LC}$ \\
\hline Psammophis schokari & Saharo-Sindian & $\mathrm{C}$ & $\mathrm{LC}$ \\
\hline $\begin{array}{l}\text { Spalerosophis } \\
\text { dolichospilus }\end{array}$ & Maghrebin & $\mathrm{C}$ & DD \\
\hline Hemmorhois hippocrepis & $\begin{array}{l}\text { Ibero- } \\
\text { Maghrebin }\end{array}$ & $\mathrm{C}$ & $\mathrm{LC}$ \\
\hline Daboia mauritanica & Maghrebin & $\mathrm{C}$ & NT \\
\hline Cerastes cerastes & Saharan & $\mathrm{C}$ & $\mathrm{LC}$ \\
\hline Eryx jaculus & Saharan & $\mathrm{C}$ & $\mathrm{LC}$ \\
\hline
\end{tabular}

* Species protected by Algerian legislation:

- Decree No 83-509 of 20 August 1983 relating to protected non-domestic animal species,

- Presidential Order No 06-05 of 15 July 2006 relating to the protection and preservation of certain animal species threatened with extinction.

LC: Least Concern; NT: Near Threatened; DD: Data Deficient; I: Insectivore; C: Carnivore; H: Herbivore.

Ibero: Ancient people of Western Europe.

IUCN: International Union for Conservation of Nature.

The 22 species of reptiles sampled show a clear dominance of the biogeographical categories: Saharan (27.27\% with 6 species) and Maghrebian $(22.73 \%$ with 5 species), followed by the moderately represented Ibero-Maghrebian (18.17\% with 4 species), Mediterranean and Saharo-Sindian $(13.64 \%$ with 3 species each), followed by the North African (4.55\% with one species). The species were grouped into the following trophic categories (Table 2): insectivores (50\%; 11 species), carnivores (40.91\%; 9 species), and herbivores (9.09\%; 2 species).
Table 3. Distribution by habitat of inventoried reptile species in the study area.

\begin{tabular}{|l|c|c|c|c|c|}
\hline \multirow{2}{*}{ Species } & \multicolumn{5}{|c|}{ Habitats } \\
\cline { 2 - 6 } & MR & MB & DY & WB & HM \\
\hline Testudo graeca & 1 & 5 & 63 & 4 & 2 \\
\hline Mauremys leprosa & 0 & 0 & 0 & 3 & 0 \\
\hline Eryx jaculus & 0 & 0 & 1 & 0 & 0 \\
\hline Chamaeleo chamaeleon & 1 & 0 & 0 & 0 & 0 \\
\hline Chalcides mertensi & 0 & 0 & 1 & 0 & 0 \\
\hline Chalcides ocellatus & 0 & 6 & 6 & 8 & 3 \\
\hline Mesalina olivieri & 0 & 0 & 3 & 0 & 0 \\
\hline Acanthodactylus erythrurus & 0 & 0 & 3 & 0 & 0 \\
\hline Psammodromus algirus & 40 & 0 & 0 & 0 & 0 \\
\hline Tarentola mauritanica & 3 & 0 & 0 & 0 & 0 \\
\hline Stenodactylus sthenodactylus & 0 & 0 & 2 & 0 & 2 \\
\hline Uromastix acanthinurus & 0 & 2 & 1 & 0 & 0 \\
\hline Trapelus mutabilis & 0 & 2 & 4 & 0 & 7 \\
\hline Agama impalearis & 0 & 0 & 0 & 0 & 2 \\
\hline Varanus griseus & 0 & 0 & 4 & 0 & 0 \\
\hline Malpolon monspessulanus & 0 & 0 & 0 & 1 & 0 \\
\hline Psammophis schokari & 0 & 0 & 0 & 1 & 0 \\
\hline Spalerosophis dolichospilus & 0 & 0 & 0 & 2 & 0 \\
\hline Hemmorhois hippocrepis & 0 & 2 & 0 & 2 & 0 \\
\hline Daboia mauritanica & 1 & 1 & 0 & 0 & 0 \\
\hline Cerastes cerastes & 0 & 0 & 3 & 0 & 0 \\
\hline Trogonophis wiegmanni & 0 & 0 & 1 & 0 & 0 \\
\hline Total & 46 & 18 & 92 & 21 & 16 \\
\hline & & & 193 & & \\
\hline
\end{tabular}

MR: Mountain ridge; MB: Mountain bottom; HM: Hamada; DY: Daya; WB: Wadi bed.

\section{Spatial distribution}

Table 3 reports the distribution across habitats of the 193 reptilian individuals recorded.

The $D Y$ had the highest number of counted individuals with a rate of $47.67 \%$ and 12 different species. The species counted were characteristic of this biotope and they were dominated by Testudo graeca.

The $M R$ came second according to the richness of reptile specimens with a rate of $23.83 \%$ and 5 different species. Psammodromus algirus was dominant. Tarentola mauritanica was also found there.

The $W B$, which is a wetland, came third, showing a rate of $10.88 \%$ with 7 different species.

$M B$ occupied the penultimate position with a rate of $9.33 \%$ and 6 different species.

The $H M$ was the poorest habitat with only 5 recorded species, with a rate of $8.29 \%$. Trapelus mutabilis was the dominant species with 7 specimens.

\section{Community structure}

The calculation of abundance and occurrence frequencies in percentages for the various families recorded ac- 


\begin{tabular}{|c|c|c|c|c|c|c|c|c|c|c|c|c|c|c|}
\hline \multirow{3}{*}{$\sum$} & 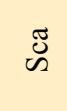 & $\begin{array}{l}\stackrel{\overrightarrow{0}}{4} \\
>\end{array}$ & 1 & 1 & ' & 菖 & 1 & $\underset{>}{\stackrel{\overrightarrow{0}}{<}}$ & : & 1 & 1 & 1 & 1 & 1 \\
\hline & 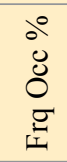 & $\tilde{\kappa}$ & 0 & 0 & 0 & $\begin{array}{l}\stackrel{\text { సे }}{ \pm}\end{array}$ & 0 & $\tilde{n}$ & $\begin{array}{l}\hat{n} \\
\infty \\
i\end{array}$ & 0 & 0 & 0 & 0 & 0 \\
\hline & 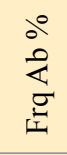 & $\stackrel{\sim}{\simeq}$ & 0 & 0 & 0 & $\begin{array}{l}\stackrel{n}{n} \\
\stackrel{\infty}{a}\end{array}$ & 0 & $\stackrel{\sim}{\simeq}$ & $\begin{array}{l}\text { त̂ } \\
\text { in }\end{array}$ & 0 & 0 & 0 & 0 & 0 \\
\hline \multirow{3}{*}{$\stackrel{3}{3}^{\infty}$} & ש్ & 这 & $\overrightarrow{0}$ & 1 & 1 & $\ddot{\ddot{Z}}$ & 1 & 1 & 1 & 1 & 荵 & 这 & 1 & 1 \\
\hline & 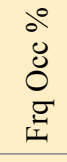 & $\stackrel{m}{m}$ & 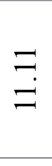 & 0 & 0 & $\stackrel{m}{m}$ & 0 & 0 & 0 & 0 & $\begin{array}{l}\underset{\text { N}}{\mathrm{N}} \\
\text {. }\end{array}$ & $\begin{array}{l}\stackrel{\forall}{+} \\
\underset{f}{*}\end{array}$ & 0 & 0 \\
\hline & 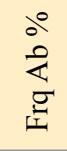 & $\begin{array}{l}\stackrel{n}{a} \\
\stackrel{a}{a}\end{array}$ & $\begin{array}{l}\text { ָे } \\
\text { I }\end{array}$ & 0 & 0 & $\stackrel{\substack{0 \\
\infty}}{\infty}$ & 0 & 0 & 0 & 0 & ñ & $\begin{array}{l}t \\
\stackrel{0}{9}\end{array}$ & 0 & 0 \\
\hline \multirow{3}{*}{$\grave{\Delta}$} & שू & $u$ & 1 & 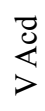 & 1 & 导 & 䓠 & $\underset{>}{\stackrel{\vec{k}}{\Delta}}$ & J & 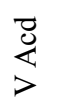 & I & 1 & $\begin{array}{l}\overrightarrow{0} \\
\dot{8} \\
>\end{array}$ & 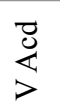 \\
\hline & 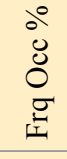 & $\begin{array}{l}m \\
m \\
n\end{array}$ & 0 & $\stackrel{\overbrace{}}{m}$ & 0 & $\begin{array}{l}\stackrel{0}{0} \\
\stackrel{0}{0}\end{array}$ & $\begin{array}{l}\hat{\sigma} \\
\underline{0}\end{array}$ & $\stackrel{m}{n}$ & $\begin{array}{l}\hat{\sigma} \\
\stackrel{0}{0}\end{array}$ & $\begin{array}{l}\hat{6} \\
\dot{0}\end{array}$ & 8 & 0 & ڤ్ర & $\stackrel{m}{m}$ \\
\hline & 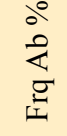 & $\begin{array}{l}\stackrel{\infty}{+} \\
\infty \\
0\end{array}$ & 0 & $\stackrel{\circ}{\circ}$ & 0 & $\underset{\vec{\sigma}}{\sim}$ & గึ & $\vec{i}$ & $\underset{i n}{f}$ & $\stackrel{m}{m}$ & 0 & 0 & $\begin{array}{l}\text { ị } \\
\text { ñ }\end{array}$ & $\stackrel{\rho}{-}$ \\
\hline \multirow{3}{*}{$\stackrel{m}{\Sigma}$} & ש్ & 芯 & 1 & 1 & 1 & 这 & 1 & I & : & 1 & 1 & 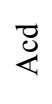 & $\underset{>}{\overrightarrow{0}}$ & 1 \\
\hline & 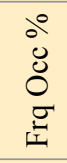 & $\stackrel{n}{\mathfrak{I}}$ & 0 & 0 & 0 & $\approx$ & 0 & 0 & $\approx$ & 0 & 0 & $\stackrel{\sim}{i}$ & त̂̀ & 0 \\
\hline & 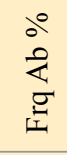 & $\underset{\stackrel{\infty}{\sim}}{\stackrel{\infty}{\sim}}$ & 0 & 0 & 0 & $\stackrel{m}{m}$ & 0 & 0 & $\begin{array}{l}\text { त̃ } \\
\text { ते }\end{array}$ & 0 & 0 & $\begin{array}{l}\exists \\
\exists\end{array}$ & 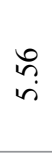 & 0 \\
\hline \multirow{3}{*}{$\tilde{z}$} & ש్ & 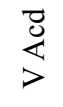 & 1 & 1 & $\stackrel{\overrightarrow{0}}{\mathbb{8}}$ & 1 & 0 & 导 & 1 & 1 & 1 & 1 & $\begin{array}{l}\overrightarrow{0} \\
> \\
>\end{array}$ & 1 \\
\hline & 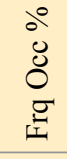 & $\begin{array}{l}\stackrel{0}{n} \\
\stackrel{n}{n}\end{array}$ & 0 & 0 & 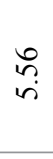 & 0 & 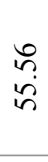 & $\begin{array}{l}\exists \\
\exists\end{array}$ & 0 & 0 & 0 & 0 & 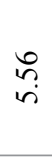 & 0 \\
\hline & 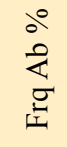 & $\overline{\bar{i}}$ & 0 & 0 & $\stackrel{\vec{i}}{\mathrm{i}}$ & 0 & 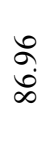 & గึ่ & 0 & 0 & 0 & 0 & $\stackrel{\bar{i}}{i}$ & 0 \\
\hline & & 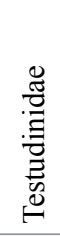 & 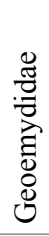 & 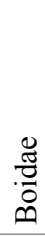 & 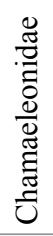 & 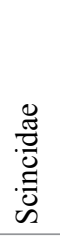 & 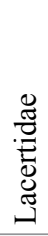 & 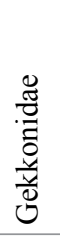 & 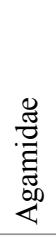 & 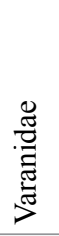 & 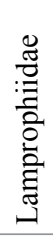 & $\begin{array}{l}\frac{\pi}{0} \\
\frac{\pi}{2} \\
\frac{0}{0} \\
0\end{array}$ & 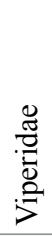 & 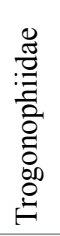 \\
\hline
\end{tabular}


cording to habitats gives us an overview of the numerical importance of the various species recorded (Table 4).

In the MR, the most abundant family was found to be Lacertidae with a rate of $86.96 \%$; thus, individuals of Psammodromus algirus were easily detectable under clumps of plants. The families with low abundances were: Gekkonidae $(6.52 \%$ of Tarentola mauritanica) and even less abundant Testudinidae, Chamaeleonidae and Viperidae (Daboia mauritanica), all with a rate of $2.17 \%$ (Table 4 ).

In the DY, considered the richest habitat for reptiles, Testudinidae was the most abundant family with a rate of $68.48 \%$; it was also easy to encounter the Greek tortois Testudo graeca there. The families Scincidae, Lacertidae and Agamidae (respectively 7.61\%, 6.52\% and $5.44 \%$ ) were accidentally abundant, while other families such as Boidae, Gekkonidae, Varanidae, Viperidae and Trogonophiidae were present but very accidentally.

The WB, considered a humid habitat, was thus favourable for 5 families with occurrence frequencies alternating between accessory for Scincidae (38.10\%), Testudinidae (19.05\%) and Colubridae (19.04\%), and accidental for Geoemydidae (14.29\%) and Lamprophiidae (9.52\%).

The environments that were poor in reptile species were the habitats of MB and HM; apart from their stony and rocky nature, they were dry and sparsely covered with vegetation. The Agamidae (22.22\% and 56.25\%, respectively) were the most abundant, followed by the Scincidae (33.33\% and $18.75 \%$, respectively), and to a lesser degree the Testudinidae (27.78\% and $12.5 \%$, respectively).

\section{Richness, diversity and equi-repartition of the inven- toried populations}

To characterise the specific diversity of the reptile populations sampled by habitat, we calculated the following ecological parameters (Table 5).

The highest value of total richness was noted in the DY with 12 species. The WB was represented by 7 species, while the lowest total richness value was observed in the HM and MR environments with 5 species each. The highest value of average richness was noted in the

Table 5. Total species richness (S), mean specific richness (Sm), Shannon diversity index (H') and equi-repartition (E) according to habitats types.

\begin{tabular}{|l|c|c|c|c|c|}
\hline & MR & MB & DY & WB & HM \\
\hline S & 5 & 6 & 12 & 7 & 5 \\
\hline Sm & 0.28 & 0.38 & 0.40 & 0.78 & 0.24 \\
\hline H' & 0.79 & 2.33 & 1.84 & 2.45 & 2.10 \\
\hline E & 0.34 & 0.90 & 0.53 & 0.87 & 0.90 \\
\hline
\end{tabular}

MR: Mountain ridge; MB: Mountain bottom; HM: Hamada; DY: Daya; WB: Wadi bed.
WB environment with 0.78 species followed by the DY environment with 0.40 species, and the lowest value was in the HM environment with 0.24 species. The values of the Shannon diversity index varied between 0.79 and 2.45 for all habitats, and all environments were more or less diverse except for the MR environment where the lowest value of 0.79 was recorded. The values of the equitability index (equi-repartition) according to the habitats tended towards 1 and varied between 0.34 and 0.90 , which indicates a certain balance between the populations except for the MR (Table 5).

\section{Spatial similarity of the studied populations}

Sorensen's index is a very simple measure of the similarity of populations, ranging from 0 , when there are no common species between the two communities studied, to 1 , when the same species exist in both communities. The values obtained between each two habitats are shown in Table 6.

Table 6. Sorenson's similarity index (\%) among the habitats of the study area.

\begin{tabular}{|l|c|c|c|c|c|}
\hline & MR & MB & DY & WB & HM \\
\hline HM & 10.00 & 27.27 & 23.53 & 16.67 & $100 \%$ \\
\hline WB & 08.33 & 23.08 & 10.53 & $100 \%$ & \\
\hline DY & 05.88 & 22.22 & $100 \%$ & & \\
\hline MB & 18.18 & $100 \%$ & & & \\
\hline MR & $100 \%$ & & & & \\
\hline
\end{tabular}

MR: Mountain ridge; MB: Mountain bottom; HM: Hamada; DY: Daya; WB: Wadi bed.

\section{Distribution of reptilian species according to habitats}

For the FCA analysis, the eigenvalues of axis $1(0.958)$ and axis $2(0.502)$ indicate that there is a significant dependence between rows and columns (Table 7). Thus, there is a significant difference between the habitats and the reptile distribution. Figure 3 shows the distribution of species and habitats according to stations. The inertia is expressed on axis $1(47.5 \%)$ and axis 2 (24.9\%); the information on the two main axes shows the spatial effect on the distribution of reptiles. Axis 1 only appears in the MR habitat in a positive position, while axis 2 appears in a positive position for the DY habitat and then

Table 7. Values of axes resulting from the FCA analysis.

\begin{tabular}{|c|c|c|c|}
\hline \multirow{2}{*}{ Dimension } & \multirow{2}{*}{ Inertia } & \multicolumn{2}{|c|}{ Proportion of inertia (\%) } \\
\cline { 3 - 4 } & & Explained & Cumulated \\
\hline 1 & 0.958 & 47.5 & 47.5 \\
\hline 2 & 0.502 & 24.9 & 72.4 \\
\hline 3 & 0.396 & 19.7 & 92.1 \\
\hline 4 & 0.160 & 7.9 & 100 \\
\hline
\end{tabular}


in a negative position for the HM, MB and WB habitats. Thus, there are four groups according to the reptile composition of the studied environments (Table 7).

Group 1 corresponds to the MR habitat, whose characteristic species are Psammodromus algirus, Tarentola mauritanica and Chamaeleo chamaeleon.

Group 2 represents the most species-rich habitat that is DY, where the presence of humidity and dense and varied vegetation is an essential factor for the development of Testudo graeca, Mesalina olivieri, Acanthodactylus erythrurus, Stenodactylus sthenodactylus, Varanus griseus, Eryx jaculus, Chalcides mertensi, Trogonophis wiegmanni and Cerastes cerastes.

Group 3 consists almost entirely of two similar habitats, namely HM and MB (rocky and stony environments), which are the least rich in species, with only 3 species: Trapelus mutabilis, Agama impalearis and Uromastyx acanthinurus.

Group 4 represents the WB habitat hosting the following species: Hemmorhois hippocrepis, Spalerosophis dolichospilus, Psammophis schokari, Mauremys leprosa and Malpolon monspessulanus.

There is a linkage through some species that do not strictly belong to any group, in this case the MB habitat of Group 3 and Group 1 (Daboia mauritanica) and the MB habitat of Group 3 and Group 4 (Chalcides ocellatus).

\section{DISCUSSION}

The usefulness of this study is justified by the lack of data on reptiles in M'sila region, in addition to the fact that its ecosystems are under intense anthropic pressure which is constantly aggravating the situation. The impact of desertification caused the disappearance of certain species such as Uromastyx acanthinurus and Daboia mauritanica, whose conservation status is becoming almost threatened according to the IUCN.

This inventory is not exhaustive, but it can give a general view of the reptile fauna in the study area, while awaiting comparable, more extensive studies involving other habitats. Comparatively, in the Aurès massif (eastern Algeria), a much higher number of 41 species of reptiles were recorded (Chirio and Blanc 1997). On the coast, in the El Kala National Park (north-east Algeria), Rouag and Benyakoub (2006) recorded 17 species of reptiles over an area of 76438 ha. In the south of Kabylie (north-central Algeria), Mamou et al. (2014) recorded 18 species of reptiles. In the region of Tiaret and Chlef (north-west Algeria), Ferrer et al. (2016) recorded 22 species of reptiles. According to Rouag (2012), two major biogeographical entities can be distinguished in Algeria: Mediterranean (42\%) and Saharan (34\%). However, the dominant biogeographical elements in M'sila region are the Saharan entities followed by the Maghrebian ones, then the least

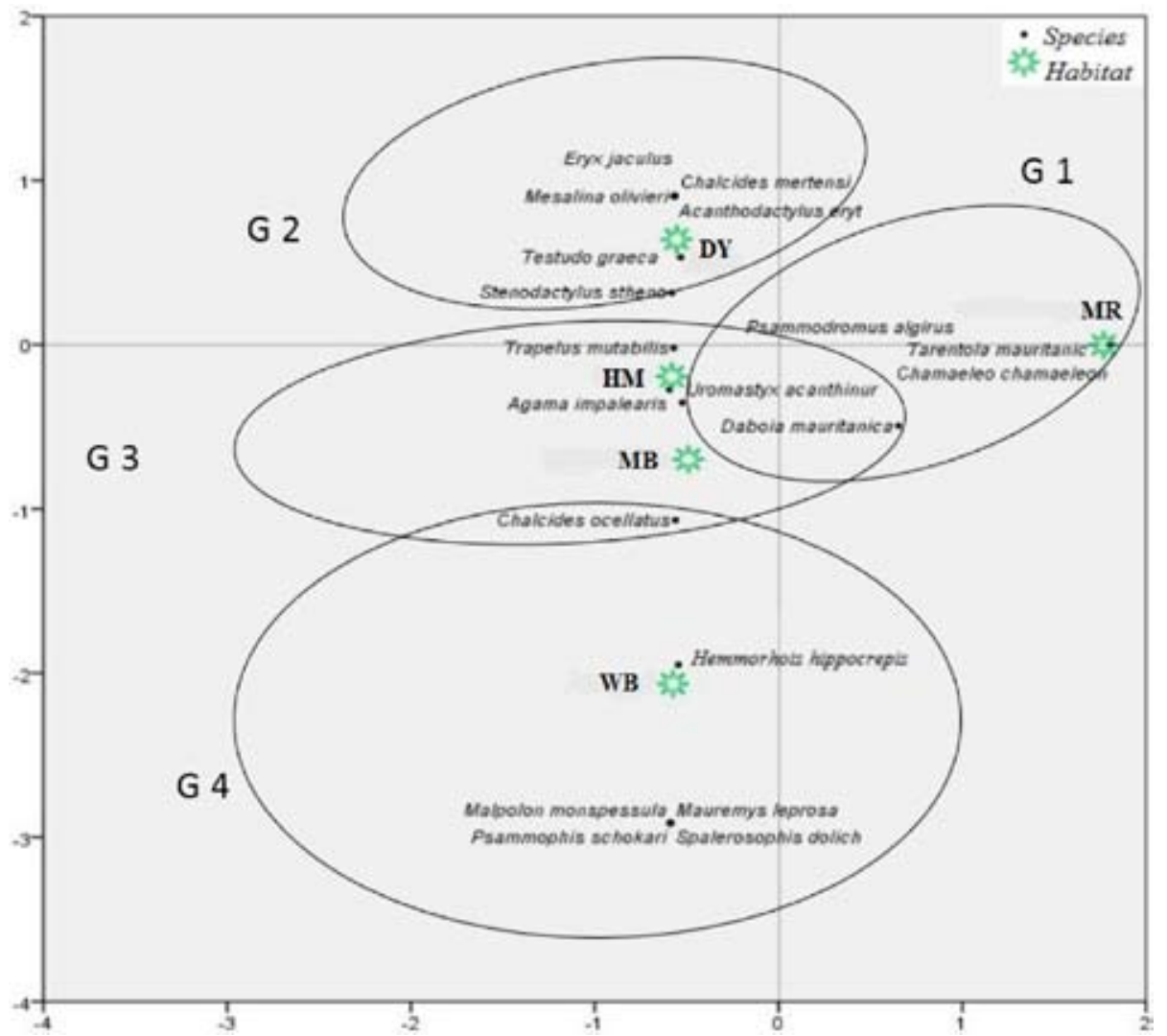

Figure 3. Factorial correspondence analysis by habitats of the study area. MR: Mountain ridge; MB: Mountain bottom; HM: Hamada; DY: Daya; WB: Wadi bed. 
present are the Mediterranean and the North African entities which tend to retreat towards the northern, more humid biotopes. The results of the above research and the distribution of reptiles, established by Rouag (2012), confirm that the region of the present study belongs to the northern entity of the country. This entity, which extends from the coast to the southern limits of the Saharan Atlas, is thought to contain between 20 and 30 species of reptiles. Furthermore, it appears that out of a total of 80 reptile species recorded in Algeria (Rouag 2012), our study region shelters $27.5 \%$ of species.

Most Mediterranean reptile species are lizards (67\%) and snakes (27\%) (CEPF 2017). Rouag (2012) reported similar values for Algeria concerning lizards $(63 \%)$ and snakes (31\%). This corroborates with our results, since lizards are the most represented reptiles in the study area with 54.5\% (12) of species, followed by snakes with $31.8 \%$ (7) of species and turtles with 9\% (2) of species.

It seems that the region of the present study is a transition zone between the steppe (medium arid climate) and the Tell (mountainous region with a lower semi-arid bioclimate). It is seriously threatened by desertification due to a very high anthropic pressure (Beddek 2017). The majority of reptile species listed are specific to territories with an arid climate, which is characterized by strong heat surges and lower humidity levels. This is what reinforces our finding about the desertification of the study region. According to Dreux (1980), temperature is a major factor influencing the geographical distribution of animal species. In addition, amphibians and reptiles are expected to be particularly sensitive to climate change due to their ectothermy (Beddek 2017).

In terms of trophic categories, insect-eating reptiles dominate and herbivores are poorly represented, as most lizards feed on insects (Schleich et al. 1996). The category of carnivores is in second place with 9 species, almost all of which are snakes, and which feed mainly on lizards and small mammals, especially rodents (Gruber 1992). It is interesting to note the presence of 7 protected species in Algeria, including two species that are Near Threatened according to the IUCN.

It is noted that the DY habitat contains the highest number of species and individuals captured (lizards and tortoises), with a clear dominance of Testudo graeca. It is suggested that the dominance of Testudo graeca in the DYs is due to the effect of the large size of this species and the poor ground cover, allowing its easy tracking compared to other reptilian species. Although DYs as habitats would provide a rich and diverse fauna and flora for reptile feeding, some researchers believe that their conservation status according to IUCN has worsened, especially for Testudo graeca, due to habitat loss and fragmentation (Graciá et al. 2020).

The MR habitat is mainly a favourable habitat for Psam- modromus algirus, one of the most common Mediterranean Lacertids (Bouam et al. 2016). In Algeria, this reptile is reported much more in the mountains with Mediterranean and Saharan climatic influences (Djurdjura and Belezma), at more than $1000 \mathrm{~m}$ from sea level (Mamou and Marniche 2016; Bouam et al. 2016). It reaches $2500 \mathrm{~m}$ in the Moroccan Atlas and only $1500 \mathrm{~m}$ in the Pyrenees. It is found at high densities where there is a significant shrub cover (Pleguezuelos et al. 2002).

The MB is a bright, sunny place with rocky and stony slopes, creating a favourable environment for Uromastyx acanthinura and Daboia mauritanica. The "La Fouette queue" is well known in the Sahara, this lizard occurs in all rocky and stony areas (Le Berre 1989), similar to another species of the same genus: Uromastyx ocellata, reported in Egypt in the mountains and at the foot of hills, where it inhabits gorges and rocks and which could be attributed to the terrestrial petrodophilic ecological type (Milto et al. 2019).

The Maghreb viper occupies most of the territory of Morocco, northern Algeria, Tunisia and north-western Libya, with a specific presence in northern Western Sahara (Barnestein et al. 2014). It appears to be the most generalist species in terms of habitat selection, as this snake is found both in the coastal environment, where it shares habitat with Bitis arietans, and in the more arid inland environments, where it can coexist with Cerastes cerastes and possibly Echis leucogaster (Del Marmol et al. 2019).

The WB is a more or less homogeneous habitat regarding the presence of the different types of reptiles, since turtles, lizards and snakes are found in it. Wadis, small streams with clear water and rocky bottoms, ponds with muddy bottoms and mountain torrents are the favourite habitats of Mauremys leprosa (Fretey 1987). This species is therefore very water-linked, but inland it seems to be becoming rarer, existing in small populations in permanent Wadis (Rouag 2012). Chalcides ocellatus also prefers this humid habitat, similar to our study area, and can be found elsewhere in Algeria around lakes and in humid forests such as the "suberaie et zeenaie" of the El Ghorra massif where the thickness of the litter is important (Rouag 2012).

Lamprophiidae and Colubridae also prefer this environment (WB), notably Malpolon monspessulanus and Hemmorhois hippocrepis, two Mediterranean snakes that are found in sympatry, as has already been reported in the Aurès massif in the east of the country (Chirio and Blanc 1997). The Zizyphus lotus and Tamarix africana formations in the WB constitute a favourable refuge for small rodents, birds and lizards, which are essential for the feeding of these large snakes.

The presence of Spalerosophis dolichospilus and Psammophis schokari (both Saharan and Saharo-Sindian species) in the WB habitat is further evidence of a tran- 
sition between the middle arid and the lower semi-arid climate. They seem to be related to the sandy terrain of temporary or permanent Wadis (Bons 1967).

The degraded and open HM habitat allows a good camouflage for Agamidae thanks to its pebbles and stones. In Algeria, the presence of Trapelus mutabilis covers practically the whole Sahara (Rouag 2012). Frequent in the lower arid region, on rocky as well as clayey, indurated or sandy soils (Chirio and Blanc 1997). Chalcides ocellatus and Stenodactylus sthenodactylus can also be found in this habitat hidden under stones or other debris. The abundance scale reveals that only the Testudinidae family, and more specifically the species Testudo graeca, can be found in all types of habitats in the study area (constancy scale: accidental to very accidental). This species is restricted to natural and semi-natural habitats mainly characterised by Mediterranean vegetation and agricultural landscape characterised by very little management (Graciá et al. 2020).

Other families of reptiles are specific to the well distinguished habitat of DYs in the study area, but with a very accidental scale of constancy. They can be easily found in loose or sandy soil, with a more diverse fauna and flora; these are the Boidae Eryx jaculus, which prefers dry habitats (rocky or sandy hills), semi-desert coastal areas, dunes, Mediterranean forests, low-growing shrublands and meadows, cultivated fields and olive groves (Christopoulos et al. 2019).

There is also the Trogonophiidae Trogonophis wiegmanni which is an amphisbaenian living all its life buried in the ground, but is frequently found under rock (Recio et al. 2019), then, the Varanidae Varanus griseus which is considered by some authors as a sand-dwelling species (Aloufi et al. 2019), thus preferring the DY habitat.

The MRs in our study area are also a specific habitat for Chamaeleonidae (abundance scale: very accidental) and a single species of Lacertidae, Psammodromus algirus (abundance scale: constant). This species is associated with low shrub cover (Telleria et al. 2011), which justifies the omnipresence of this lizard in the higher elevations of the mountains in our study area, at the feet of plants on sloping rocky slabs and open grasslands away from degraded steppes. The Lamprophiidae (Malpolonmonspes sulanus and Psammophis schokari) are only associated with the WB habitat in the study area, with a scale of consistency: accidental.

It appears that the DY habitat is the most species-rich (12 species/30 trips) compared to the other habitats in our study area, but according to the number of field trips, the average richness puts the WB habitat in first position (7 species/9 trips), which would explain the number of species recorded in few trips.

The Shannon index clearly shows that the DYs and MRs habitats are the least diverse compared to the other habitats, which would be due to the high relative abundance of Testudo graeca in the DY and Psammodromus algirus in the MR. In other words, with the exception of these two species, all habitats could be said to have the same diversity. This is confirmed by the equitability index which indicates that in MR and DY the abundance of reptiles is concentrated in two species and that the other habitats (MB, HM, and WB) have more balanced populations of species.

The similarity between habitats is not tangible in the study area, this would be due to the heterogeneity of soil, vegetation cover and altitude. Such heterogeneity is one of the main factors supporting herpetological diversity in Morocco (Avella et al. 2019).

The factorial correspondence analysis shows that the type of habitat has a direct influence on the distribution of reptilian species in our study area (Figure 3). It allowed us to identify four groups according to the environment and their characteristic species. According to Lacoste and Salanon (2001), the microclimate is representative of the climatic conditions that prevail within an ecological station resulting from a more or less pronounced modification of the local climate under the influence of various other factors (topography, soil) as well as the biological constituents (more specifically vegetation) specific to this station.

What stands out in this distribution is the availability of dense vegetation, shelter and moisture. However, the occurrence of some reptilian species is directly related to the presence or absence of specific habitats for vital activities such as nesting, hibernation, aestivation, foraging, adult residence and terrestrial dispersal (Ali et al. 2018).

\section{CONCLUSION}

The study area located at the northern edge of the Algerian steppe in M'sila harbours 22 species of reptiles representing about $27.5 \%$ of all reptile species recorded in Algeria. In addition to the richness of reptiles in this narrow area, two species classified by IUCN as Near Threatened (Uromastyx acanthinurus and Daboia mauritanica) and one species with insufficient data (Spalerosophis dolichospilus) have been recorded.

The relative abundance of reptilian individuals was also noted to be quite low, even worrying, except for Psammodromus algirus, which prefers the higher habitats of the mountains, away from anthropological pressures. The alarming destruction of habitats by excessive ploughing of the DYs and overgrazing of the steppe rangelands would be the main causes.

These findings lead us to propose a review of the protection status of certain reptile species in Algerian regula- 
tions, notably for: Eryx jaculus which appears to be in decline (Cox et al. 2006) and Trogonophis wiegmanni which can be used as an indicator species to assess the success of conservation management in Mediterranean bioregions (Soultan et al. 2020). Specialised studies should be conducted to know and quantify the types of illegal commercial acts carried out towards reptiles in Algeria. On the other hand, it becomes essential to regulate the acquisition of exotic animals by citizens as pets or for exhibition purposes. Even more, the competent authorities should give more attention to wild fauna by further strengthening laws in order to preserve natural ecosystems.

It is also recommended to reinforce regional cooperation, exchange of expertise and the amplification of applied research programmes, and as a matter of urgency, the identification and delimitation of bio-regions with a high diversity of reptiles, which would be crucial for the implementation and conduct of conservation plans in a more efficient and easy way. The results obtained from the prospected research would later form a valuable platform for future studies on the continuing impact of climate change on herpetofauna.

\section{ACKNOWLEDGMENTS}

Authors acknowledge all the prospectors for their precious help during different sampling campaigns, especially Mr Benhenia Youcef. No funds were obtained to perform the present study.

\section{Dr Mammeri Adel ORCID: 0000-0001-8798-322X}

\section{REFERENCES}

Adjabi, A., H. Sidi, R. Bounar, and H. H. R. Naseri. 2019. Floristic distribution according to the edaphic parameters of a Steppe Zone, case of study: The Nature Reserve "El-Mergueb" M'sila, Algeria. Ekológia (Bratislava) 38 (4): 336-352. Doi: 10.2478/eko-2019-0025

Ali, W., A. Javid, A. Hussain, and S. M. Bukhari 2018. Diversity and habitat preferences of amphibians and reptiles in Pakistan: a review. Journal of Asia-Pacific Biodiversity 11: 173-187. Doi:10.1016/j.japb.2018.01.009

Aloufi, A. A., Z. S. Amr, M. A. Abu Baker, and N. Hamidan.2019. Diversity and conservation of terrestrial, freshwater, and marine reptiles and amphibians in Saudi Arabia. Amphibian \& Reptile Conservation 13 (2) [General Section]: 181-202 (e204).

Avella, I., N. Lucchini, U. Enriquez-Urzelai, F. Corga, and F. Martínez-Freiría. 2019. New records for the reptile fauna of the Tichka plateau (Western High Atlas, Morocco). Boletin Asoc. Herpetol. Esp. 30 (2).

Barnestein, J. A. M., J. P. González De La Vega, and F. Jiménezcazalla. 2014. New appointment for the distribution of Daboia mauritanica in the Rif, Morocco. Butll. Soc. Catalana Herpetologia 21. Available on http://soccatherp.org/publicacions/

Beddek, M. 2017. Lack of knowledge of biodiversity and conservation biology: the case of herpetofauna of Algeria. Biodiversity and Ecology. Montpellier University, 149 pp. https://tel.archives-ouvertes.fr/tel-01815962.

Böhm, M., D. Cook, H. Ma, A. D. Davidson, A. García, B. Tapley, P. Pearce-Kelly, and J. Carr. 2016. Hot and bothered: Using trait-based approaches to assess climate change vulnerability in reptiles. Biological Conservation. Part A. 204: 32-41. https://doi.org/10.1016/j.biocon.2016.06.002.

Bons, J. 1967. Research On the biogeography and biology of Amphibians and Reptiles of Morocco. Doctoral thesis Sciences Nature. Montpellier, CNRS AO 2345, $321 \mathrm{pp}$.

Bons, J., and A. Geniez. 1996. Amphibians and reptiles of Morocco (Western Sahara included): biogeographic atlas. _Spanish Herpetological Association, 320 pp.

Bouam, I., A. Necer, M. Saoudi, L. Tahar-Chaouch, and F. Khelfaoui. 2016. Diet and daily activity patterns of the lacertid lizard Psammodromus algirus (Sauria: Lacertidae) in a semi-arid Mediterranean region. Zoology and Ecology 26 (3): 244-252. http://dx.doi.org/10.1080/21658005.2016.1196989.

Boulenger, G. A. 1891. Catalogue of the Reptiles and Batrachians of Barbary (Morocco, Algeria, Tunisia), based chiefly upon the Notes and Collections made in 1880-1884 by M. Fernand Lataste. Trans. zool. Soc., London: 8: 93-164.

Bouazza, A., and A. Rihane. 2021. Checklist of amphibians and reptiles of Morocco: taxonomic update and standard Arab names. Herpetology Notes 14: 1-14.

Brito, J. C., P. Tarroso, C. G. Vale, F. Martínez-Freiría, Z. Boratynski, J. C. Campos, S. Ferreira, R. Godinho, D. V. Gonçalves, J. V. Leite, V. O. Lima, P. Pereira, X. Santos, M. J. Ferreira da Silva, T. L. Silva, G. VeloAntón, J. Veríssimo, P-A. Crochet, J. M. Pleguezuelos, and S. B. Carvalho. 2016. Conservation Biogeography of the Sahara-Sahel: additional protected areas are needed to secure unique biodiversity. Diversity and Distributions 22 (4): 371-384. Doi: 10.1111/ddi.12416.

Bush, E. R., S. E. Baker, and D. W. Macdonald. 2014. Global trade in exotic pets 2006-2012. Conservation Biology 28 (3): 663-676. https://doi.org/10.1111/cobi.12240

Carter, A. L., and F. J. Janzen. 2021. Predicting the effects of climate change on incubation in reptiles: methodological advances and new directions. Journal of Experimental Biology 224. (Suppl. 1.) jeb236018. doi: $10.1242 / \mathrm{jeb} .236018$. 
CEPF. 2017. Mediterranean Basin Biodiversity Hotspot. The Critical Ecosystem Partnership Fund.

Chirio, L., and C. H. Blanc. 1997. Status and distribution of Reptiles in the Aures massif (Algeria). Journal of African Zoology 111 (3): 216-233. www.researchgate.net/publication/281936105

Christopoulos, A., A.-G. Verikokakis, V. Detsis, I. Nikolaides, L. Tsiokos, P. Pafilis, and G. Kapsalas. 2019. First records of Eryx jaculus (Linnaeus, 1758) from Euboea Island, Greece (Squamata: Boidae). Herpetology Notes 12: 663-666.

Çiçek, K., and O. Cumhuriyet. 2017. Amphibians and Reptiles of the Mediterranean Basin. Intech Open. Mediterranean Identities, Environment, Society, Culture: 204-237. DOI: 10.5772/intechopen.70357.

Cox, N., J. Chanson, and S. Stuart. 2006. The Status and Distribution of Reptiles and Amphibians of the Mediterranean Basin. IUCN, Gland, Switzerland and Cambridge, UK, 50 pp.

Crump, M. A., and N. J. Scott. 1994. Visual encounter surveys. In W.R. Heyer, M. A. Donnelly, R.W. Mc Diarmid, et al. (eds) Measuring and Monitoring Biological Diversity: Standard Methods for Amphibians. Washington, DC: Smithsonian Institution Press, 84-91 pp.

Das, I. 2016. Rapid assessments of reptile diversity. Reptile Ecology and Conservation: A Handbook of Techniques, 241-253 pp.

Dellaoui, B., M. Beddek, O. Peyre, P. Geniez, B. Allegrini, F. Koudache, and P.-A. Crochet. 2015. Rediscovery of Acanthodactylus spinicauda Doumergue, 1901 in Algeria. Herpetology Notes 8: 511-515.

Del Marmol, G. M., B. R. Fernandez, S. Clerc, T. Håkonsen, S. Acierno, and M. Sassoè-Pognetto. 2019. New cases of sympatry between Vipers in southwestern Morocco. Herpetology Notes 12: 337-342.

Delzons, O., Y. Adam, C. Béranger, B. Frochot, J. Gourvil, P. Lecomte, and M. Parisot-Laprun. 2015. Guide to ecological diagnostic methods for natural environments. Application aux sites de carrière UNPG, 3 rue Alfred Roll 75849. Paris Cedex p.17.390 environnement@ unicem.fr.

Doumergue, F. 1901. Essay on the Herpetological fauna of Orania with analytical tables and concepts for the determination of all reptiles and amphibians of Morocco, Algeria and Tunisia. Bulletin of the Archaeological Geography Society of Oran XIX à XXI.

Dreux, P. 1980. Precise ecology. Ed. Presses Univ. France (P. U. F.), Paris, 231 pp.

Ferrer, J., W. Dahmani, M. Ait Hammou, A. S. Camarasa, M. Maatoug, and D. Sanuy. 2016. Contribution to the connection of the herpetofauna of the North Algeria (regions of Tiaret and Chlef). Butlleti de la Societat Catalana Herpetologia 23: 44-63.

Foufopoulos, J., A. Marm Kilpatrick, and A. R. Ives. 2011. Climate Change and Elevated Extinction
Rates of Reptiles from Mediterranean Islands. The American Naturalist 177 (1): 119-129. Doi: https://doi.org/10.1086/657624.

Fretey, J. 1987. The reptiles of metropolitan France and satellite islands: Tortoises and Lizards, Snakes, Venomous function France: Edition Hatier 1: 254.

Geniez, P. 2012. Amphibians and Reptiles of France: Key to determination. Ecole Pratique des Hautes Etudes. Montpellier: Center for Functional and Evolutive Ecology, 16 pp.

Gervais, P. 1835. Oral communication on the enumeration of some Reptiles sent from Barbary. Bull. Soc. Sci. Nat. France 1: 112-114.

Gervais, P. 1836. Enumeration of some species of reptiles from Barbary. Annals of natural sciences of Paris 2 (6): 308-313.

Gervais, P. 1844. On the vertebrate animals of Algeria. Annals of Natural Sciences of Paris 10: 202-208.

Graciá, E., R. Rodríguez-Caro, M. Ferrández, A. Martinez Silvestre, I. Pérez-Ibarra, R. Amahjour, C. Aranda, H. A. Benelkadi, A. Bertolero, F. Esperón, M. A. EsteveSelma, S. Fahd, R. Pascual-Rico, A. Perera, B. Pfau, S. Pinya Fernández, X. Santos, A. Segura, M. J. Semaha, and A. Jover. 2020. From troubles to solutions: conservation of Mediterranean tortoises under global change. Basic and Applied Herpetology 34: 5-16. Doi: 10.11160/bah.196.

Gray, R-D., and M. Kennedy. 1994. Perceptual constraints on optimal foraging; a reason for departures from the ideal free distribution? Animal Behaviour 47: 469-471.

Gruber, U. 1992. Guide to the Snakes of Europe, North Africa and the Middle East. Neûchatel: Ed. Delachaux Et Niestle, 248 pp.

Guichenot, A. 1850. Natural History of Reptiles and Fishes. Scientific exploration of Algeria during the 1840s, 1841, 1842. Zoology. Paris, 144 pp.

Guyer, C., and M. A. Donnelly. 2012. Visual encounter survey. In R.W. McDiarmid, M. S. Foster, C. Guyer, et al. (eds) Reptile Biodiversity. Standard Methods for Inventory and Monitoring. Berkeley, CA: University of California Press, 218-20 pp.

Incorvaia, G. 2005. Study of potentially limiting factors in the distribution of Fennecs, Fennecus Zerda, in South Tunisia. Doctoral thesis in Veterinary Medicine. Claude-Bernard University - Lyon 1. France, 151 pp.

Jordaan, A. 2019. Geographic distribution and habitat selection in the Berg Adder, Bitis Atropos (Serpentes, Viperidae) on the Mpumalanga Escarpment, and the consequences for conservation. Magister dissertation. University of the Free State Bloemfontein, South Africa, $94 \mathrm{pp}$.

Lacoste, A., and R. Salanon. 2001. Elements of biogeography and ecology. Paris 2: 161-318.

Le Berre, M. 1989. Sahara fauna I, Fishes, Amphibians, 
Reptiles. Ed. Raymond Chabaud/Le chevalier. Paris. Coll (Terre Africaine), $328 \mathrm{pp}$.

Mamou, R. 2011. Contribution to the knowledge of amphibians and reptiles of southern Kabylia (Wilaya of Bouira and Bordj Bou Arreridj). Magister dissertation. University of Tlemcen, Algeria, $138 \mathrm{pp}$.

Mamou, R., and F. Marniche. 2016. Diet of Psammodromus algirus Linnaeus, 1758 (Reptilia: Lacertidae) in Djurdjura, northern Algeria. Bulletin of the Herpetological Society of France 159: 33-46.

Mamou, R., A. Boissinot, M. Bensidehoum, M. Amroun, and F. Marniche. 2014. Inventory of herpetofauna in southern Kabylia (Bouira and Bordj Bou Arreridj) Algeria. Ivorian Journal of Science and Technology 23: 259-273.

Milto, K. D., S. A. Saber, A. M. Nagy, R. A. Nazarov, D. A. Melnikov, and N. B. Ananjeva. 2019. First report on the Reptile diversity of Wadi El Gemal National Park, Eastern Desert, Egypt. Russian Journal of Herpetology 26 (3): 175-184. Doi: 10.30906/1026-2296-2019-26-3-175-184.

Musah, Y., B. Y. Ofori, and D. K. Attuquayefio. 2019. Herpetofauna community diversity and composition of a changing coastal wetland in Ghana. West African Journal of Applied Ecology 27 (1): 52-65.

Pleguezuelos, J. M., R. Márquez, and M. Lizana. 2002. Atlas and Red Book of Amphibians and Reptiles of Spain. Directorate General for the Conservation of NatureSpanish Herpetological Association (2nd impression). Madrid, 587 pp.

Poiret, J. L. M. 1789. Letters written from ancient $\mathrm{Nu}$ midia during the years $1785 \& 1786$, on religion, customs \& the walls of the Moors \& Arab-Bedouin; with an essay on the natural history of this country. Paris, Chez J. B. F. Born in La Rochelle. http://www.biodiversitylibrary.org/item/69067.

Recio, P., G. Rodriguez-Ruiz, J. Ortega, and J. Martin. 2019. PIT-Tags as a technique for marking fossorial reptiles: insights from a long-term field study of the amphis baenian Trogonophis wiegmanni. Acta Herpetologica 14 (2): 101-107. DOI: 10.13128/a h-7747.

Rodrigues, P., R. Figueira, P. Vaz Pinto, M. B. Araújo, and P. Beja. 2015. A biogeographical regionalization of Angolan mammals. Mammal Review 45 (2): 103-116. https://doi.org/10.1111/mam.12036.

Rouag, R. 2012. Biodiversity of Algerian herpetofauna. Technical report: $104 \mathrm{pp}$.

Rouag, R., and S. Benyacoub. 2006. Inventory and ecology of Reptiles in El Kala National Park. Bulletin of the Herpetological Society of France 117: 25-40.

Rozet, C. A. M. 1833. Travel to the Regency of Algiers or description of the country occupied by the French army in Africa. Vol 3. Paris: Arthus Bertrand Librairie, 95 pp.

Schleich, H. H., W. Kästle, and K. Kabisch. 1996. Amphib- ians and Reptiles of North Africa. Koenigstein: Koeltz Scientific Books, 630 pp.

Shaw, T. 1738. Travels, or observations relating to several parts of Barbary and the Levant. Oxford University Press: Printed at the Theatre.

Soultan, A., M. Wikelski, and K. Safi. 2020. Classifying biogeographic realms of the endemic fauna in the AfroArabian region. Ecology and Evolution 10: 8669-8680. DOI: $10.1002 /$ ece 3.6562 .

Stanford, C. B., J. B. Iverson, A. G. J. Rhodin, P. P. Van Dijk, R. A. Mittermeier, G. Kuchling, K. H. Berry, A. Bertolero, K. A. Bjorndal, T. E. G. Blanck, K. A. Buhlmann, R. L. Burke, J. D. Congdon, T. Diagne, T. Edwards, C. C. Eisemberg, J. R. Ennen, G. ForeroMedina, M. Frankel, U. Fritz, N. Gallego-García, A. Georges, J. W. Gibbons, S. Gong, E. V. Goode, H. T. Shi, H. Hoang, M. D. Hofmeyr, B. D. Horne, R. Hudson, J. O. Juvik, R. A. Kiester, P. Koval, M. Le, P. V. Lindeman, J. E. Lovich, L. Luiselli, T. E. M. McCormack, G. A. Meyer, V. P. Páez, K. Platt, S. G. Platt, P. C. H. Pritchard, H. R. Quinn, W. M. Roosenburg, J. A. Seminoff, H. B. Shaffer, R. Spencer, J. U. Van Dyke, R. C. Õ. Vogt, and A. D. Walde. 2020. Turtles and tortoises are in trouble. Current Biology 30: 721-735. Available from: http://reptile-database.org [Accessed: March 27, 2017].

Strauch, A. 1862. An essay on a herpetology from Algeria. Papers from the Imperial Academy of Sciences St. Petersbourg, 86 pp.

Stuart, S. N., J. S. Chanson, N. A. Cox, B. E. Young, A. S. Rodrigues, D. L. Fischman, and R. W. Waller. 2004. Status and trends of amphibian declines and extinctions worldwide. Science (New York, N. Y.) 306: 1783-1786. Doi:10.1126/science.1103538.

Telleria, J. L., J. A. Diaz, J. Perez-Tris, E. De Juana, I. De La Hera, P. Iraeta, A. Salavador, and T. Santos. 2011. Barrier effects on vertebrate distribution caused by motorway crossing through fragmented forest landscape. Animal Biodiversity and Conservation 34 (2): 331-340. Available on: https://www.raco.cat/index.php/ABC/ article/view/248925 [Consulta: 16-04-2021].

Tristram, H. B. 1859. On the Ornithology of Northern Africa. Ibis I (4): 430.

Trape, J. F., S. Trape, and L. Chirio. 2012. Lizards, crocodiles and turtles from West Africa and the Sahara. IRD éditions, 505 pp.

Uetz, P., P. Freed, and J. Hošek. 2017. The Reptile Database. [Internet]. [Updated: 2017]. Available on: https:// reptile-database.reptarium.cz/

Venchi, A., and R. Sindaco. 2006. Annotated checklist of the reptiles of the Mediterranean countries, with keys to specific identification. Part 2 - Snakes (Reptilia, Serpentes). Annali del Museo Civico di Storia Naturale $G$. Doria, Genova, 98: 259-364. 